\title{
RESISTÊNCIA AO IMPACTO IZOD DE COMPÓSITOS DE MATRIZ POLIÉSTER REFORÇADOS COM TECIDO PURO DE RAMI *
}

\author{
Caroline Gomes de Oliveira ${ }^{1}$ \\ Janine Feitosa de Deus ${ }^{2}$ \\ Ygor de Moraes Macabu ${ }^{1}$ \\ Marcus Vinícius Fonseca Ferreira ${ }^{1}$ \\ Lucas de Almeida Pontes ${ }^{1}$ \\ Djalma Souza ${ }^{3}$ \\ Frederico Muylaert Margem ${ }^{4}$ \\ Sérgio Neves Monteiro ${ }^{5}$
}

\section{Resumo}

A busca por materiais que atendam as demandas ambientais que vem surgindo com 0 passar dos anos abre um importante mercado para a aplicação de fibras naturais. Além de biodegradáveis e provenientes de fontes renováveis, as fibras naturais possibilitam a produção de materiais compósitos de baixa densidade e com boas propriedades mecânicas. Para aumentar ainda mais essas propriedades, estuda-se o uso de tecidos de fibra natural em vez das fibras alinhas. As principais vantagens desta nova configuração são o reforço em mais de uma direção ao mesmo tempo e o fato de serem mais compactos, viabilizando a incorporação de uma fração maior de material de reforço. O presente trabalho investigou a resistência ao impacto de compósitos de matriz poliéster reforçados com tecido puro de rami, que é uma das fibras lignocellusosicas mais resistentes encontradas até hoje. Os corpos de prova foram reforçados com 1, 2 e 3 camadas de tecido e foram ensaiados num pêndulo de impacto Izod. Concluiu-se com base nos resultados que o aumento da fração volumétrica de tecido aumenta a resistência ao impacto dos compósitos.

Palavras-chave: Impacto Izod; Tecido de rami; Poliéster; Fibras naturais.

\section{IZOD IMPACT BEHAVIOR OF POLYESTER MATRIX COMPOSITES REINFORCED WITH PURE RAMIE FABRIC}

\section{Abstract}

The search for materials that meet the environmental demands that has emerged over the years opens an important market for the application of natural fibers. In addition to being biodegradable and from renewable sources, natural fibers enable the production of composite materials of low density and good mechanical properties. To further increase these properties, it is studied the use of natural fiber fabrics instead of aligned fibers. The main advantages of this new configuration are to reinforce the composite in more than one direction simultaneously and, due to their compactness, to enable the incorporation of a larger fraction of reinforcing material. This study has investigated the impact resistance of composite polyester matrix reinforced with pure ramie fabric, which is one of the strongest lignocellullosic fibers found today. The specimens were reinforced with 1,2 and 3 layers of fabric and were tested in Izod impact pendulum. Based on the results, it is concluded that increasing the volume fraction of fabric it increases the impact resistance of the composites.

Keywords: Izod impact; Ramie fabric; Polyester; Natural fibers.

1 Metallurgical and Materials Engineering, undergraduation student, Laboratory of Advanced Materials, State University of the Northern Rio de Janeiro Darcy Ribeiro, Campos dos Goytacazes, RJ - Brazil

2 Metallurgical and Materials Engineering, M. Sc., Doctor Student, Laboratory of Advanced Materials, State University of the Northern Rio de Janeiro Darcy Ribeiro, Campos dos Goytacazes, RJ - Brazil

3 Metallurgical and Materials Engineering, D. Sc., Associated Professor, Laboratory of Advanced Materials, State University of the Northern Rio de Janeiro Darcy Ribeiro, Campos dos Goytacazes, RJ - Brazil.

4 Metallurgical and Materials Engineering, D. Sc., Assistant Professor, Center of Science and Engineering, Redentor University, Itaperuna, RJ - Brazil.

5 PhD Metallurgical and Materials Engineering, PhD, Main Professor, Laboratory of Materials and Metallurgy, Military Institute of Technology, Rio de Janeiro, RJ - Brazil. 


\section{INTRODUCTION}

Increasingly society has been demanding materials having low costs and that do not harm the environment. The current trend of our society points to the pursuit of environmentally friendly materials, which can contribute to lower $\mathrm{CO} 2$ emissions, the main cause of the greenhouse effect. Following this paradigm, researchers have shown interest in the recycling of materials, the use of waste and use of natural materials [1,2].

Engineering applications of natural lignocellulosic fibers obtained from vegetables and plants are valued as an environmentally friendly alternative to replace nonrecyclable materials that result in high energy consumption, such as glass fiber composite [3]. In fact, the world has shown a high tendency to replace the fiberglass for natural fibers in typical composite applications [4,5]. The use of natural fibers has several advantages over glass fiber, for example, the cheaper cost, and due to the natural fibers are more lightweight and non-abrasive to processing equipment. Among others, some synthetic fibers (including glass one) present a risk to health when inhaled and its production is associated with $\mathrm{CO} 2$ emissions, the main cause of the greenhouse effect and responsible for global warming. None of these shortcomings apply to lignocellulosic fibers extracted from plants, which are renewable, biodegradable and do not contribute on average $\mathrm{CO} 2$ emissions by absorbing this gas throughout its life cycle [6].

The natural lignocellullosic fiber ramie has been extensively investigated in several studies, such as polymer composites, reinforced by it. These composites have presented high strength and resistance [7-9]. Seeking to improve the mechanical performance of these natural materials, the use of natural fabrics have been studied as more one alternative reinforcement to polymeric composites. Some of their advantages are the possibility to reinforce the matrix in more than one direction simultaneously and the possibility to introduce a larger fraction of natural fiber, since the fabric is more compact than the aligned fibers [10,11].

In view of these considerations, it is valid to invest in materials reinforced with ramie fabric, since it made of one of the most resistant natural fibers studied. They can provide good toughness and strength. The objective of this study was to investigate the Izod impact resistance of polyester matrix composites reinforced with different volume fractions of rami fabric.

\section{EXPERIMENTAL PROCEDURE}

The fabric used for this work was obtained by the Chinese company Rose Natural Healthy Items Wholesale. Its density was measured by the Principle of Archimedes and the value obtained is $245 \mathrm{~g} / \mathrm{m}_{2}$. After that, the fabric was cut in the mold form and the specimens with different fabric volume fractions were individually confectioned by incorporating 1, 2 and 3 fabric layers into the composite. For this, an enough quantity of polyester resin was poured into the mold and then the fabric layers were placed onto it alternately with new resin layers. 

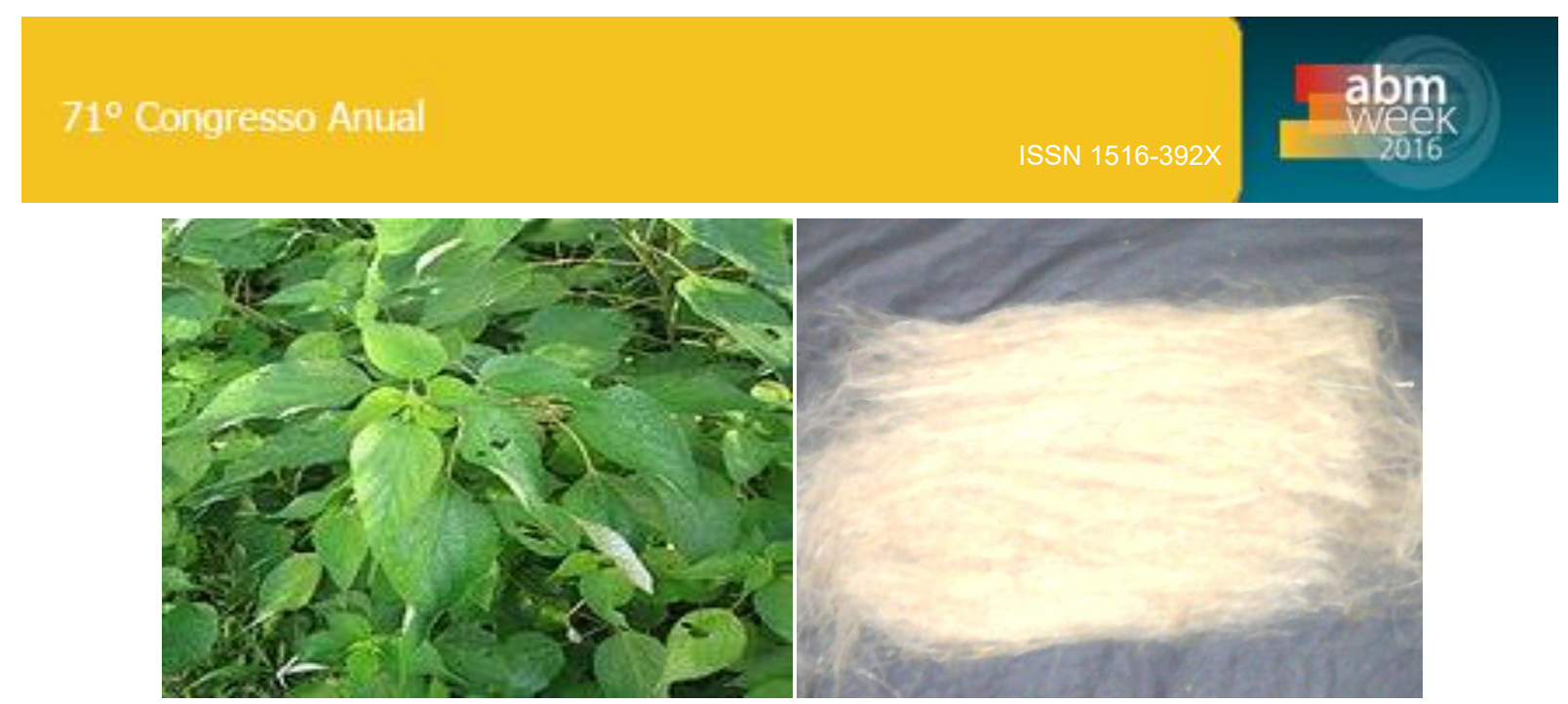

Figura 1. The ramie fiber (a) and a bundle of ramie fibers (b).

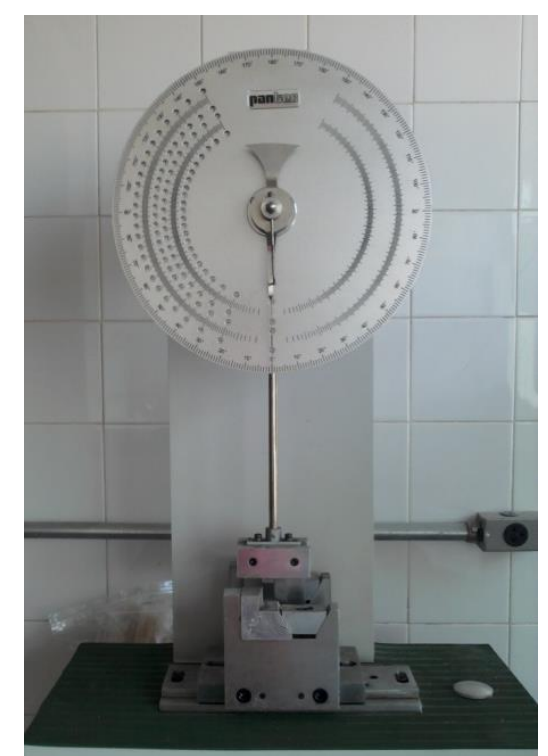

Figure 2. Izod equipment and standard specimen schematic

Plates of each composite were then cut, into bars measuring $125 \times 12,7 \times 5 \mathrm{~mm}$ which were the basis for making specimens of Charpy impact test in accordance with ASTM D256. The specimens were tested in a pendulum Pantec, Figure 2, in Izod configuration.

\section{RESULTS AND DISCUSSION}

The results of Izod impact tests of the polyester matrix composites reinforced with different volume fractions of ramie fabric are shown in Table 1.

Table 1. Izod impact energy for epoxy composites reinforced with jute fibers.

\begin{tabular}{|c|c|}
\hline Number of fabric layers & Izod Impact Energy $(\mathrm{J} / \mathrm{m})$ \\
\hline 0 & $39 \pm 12,74$ \\
\hline 1 & $144,4 \pm 28.19$ \\
\hline 2 & $235.06 \pm 28,75$ \\
\hline 3 & $353,38 \pm 46,29$ \\
\hline
\end{tabular}

Based on the results shown in Table 1, the variation of the Izod impact energy with the amount of rami fabric in the polyester composite is shown in Figure 3. 


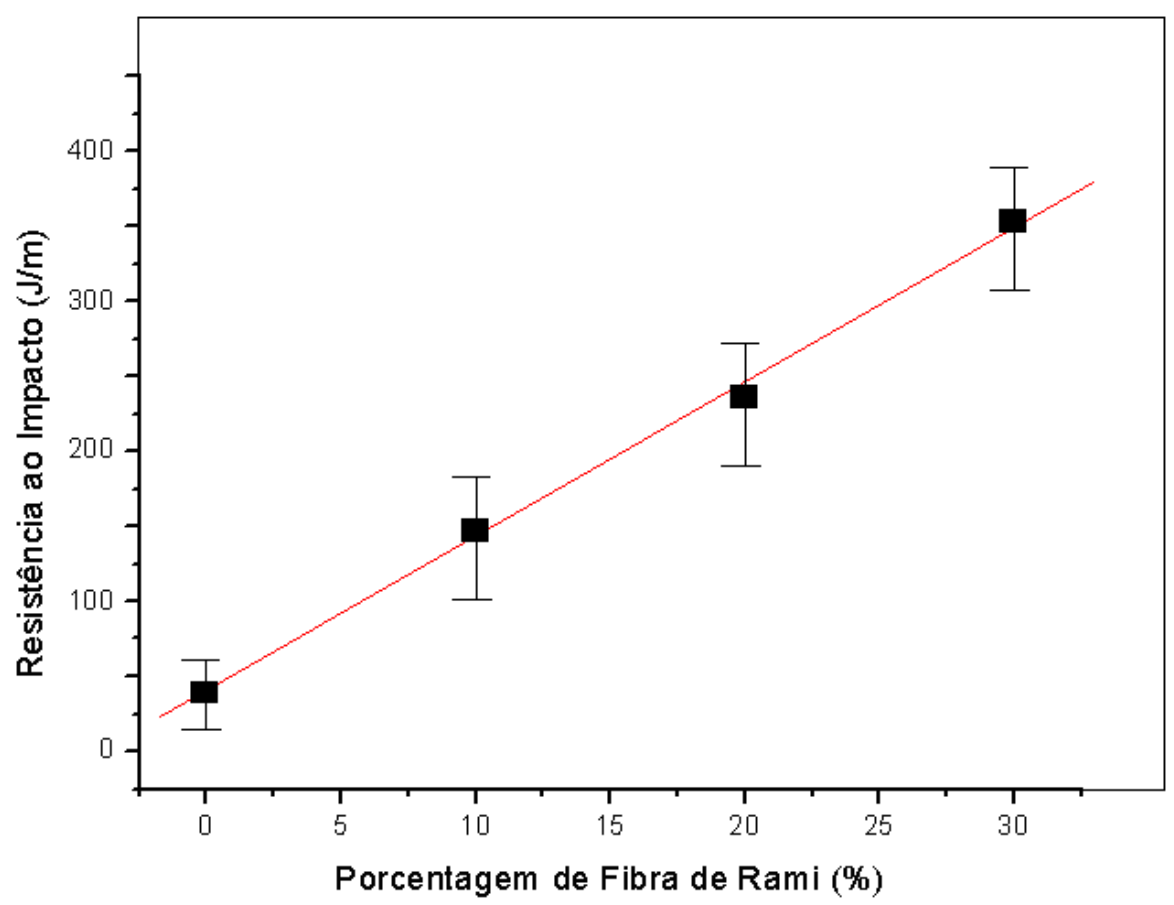

Figure 3. Izod impact energy as a function of the amount of ramie fabric.

This figure also shows the marked increase in Izod impact energy with the volume fraction of rami fabric. It is also important to note that the points relating to composites have error bars, relative to the standard deviation, relatively large. This is due to the heterogeneous nature of natural fibers, which results in substantial dispersion properties of composites reinforced by them and their fabrics.

Even considering the error bars, it is possible to interpret the increase of impact energy, i.e., toughness of the composites in Figure 3, to vary linearly with the volume fraction of ramie fabric.

Another important aspect to be discussed is the characteristic macroscopic rupture of the specimens after the test. Figure 4 illustrates a typical characteristic of rupture of the specimens of polyester composites with different volume fractions of ramie fabrics. In this figure it is shown that the test piece with 3 fabric layers, i.e, one with greater tenacity was not separated into two parts after impact.

This indicates that the crack nucleated at the impact point, spreads across the fragile early polyester matrix. With 1 layer of ramie fabric proceeds to crack the matrix to complete rupture. However from 2 layers, the crack is blocked by the fabric and rupture occurs along the interface fiber / matrix. The specimens then bends around the head of the hammer, but does not separate due to the flexibility of the fabric are not broken. Because it does not occur total rupture, Figure 4, for the specimen with 3 layers underestimate the toughness of the composite. If the fabric would have broken, causing the specimen to separate into two parts, the energy absorbed would be even greater. 


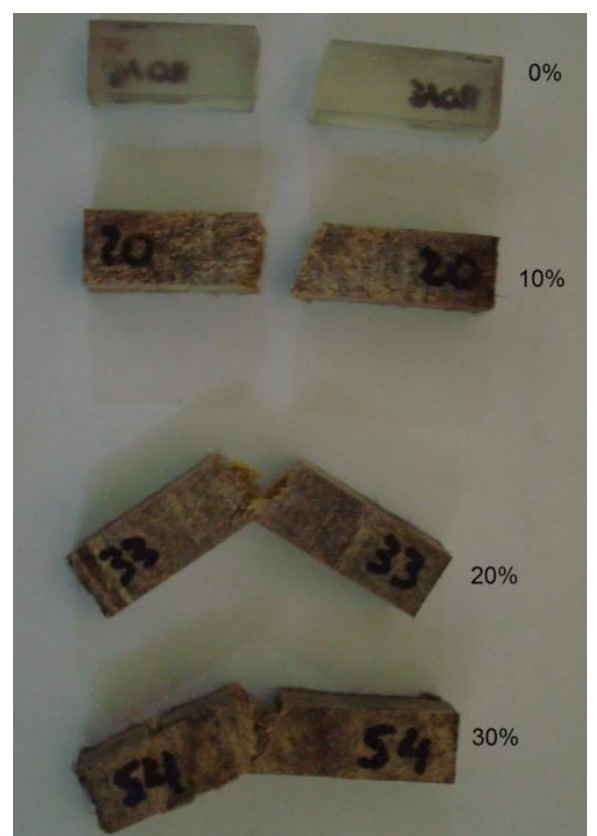

Figure 4. Typical ruptured specimens by Charpy impact tests.

The reason for having a crack nucleated at the impact point, changing its trajectory to reach the ramie fabric and to propagate through the interface with the matrix is due to the low interfacial resistance.

\section{CONCLUSION}

- Composites with ramie fabric reinforcing a polyester matrix display a significant increase in the toughness, measured by the Izod impact test, as a function of the amount of the fabric.

- Most of this increase in toughness is apparently due to the low ramie fiber/polyester matrix interfacial shear stress. This results in a higher absorbed energy as a consequence of a longitudinal propagation of the cracks throughout the interface, which generates larger rupture areas, as compared to a transversal fracture.

- Amounts of fabric above 1 layer are associated with incomplete rupture of the specimen owing to the bend flexibility, i.e., flexural compliance, of the ramie fabric.

\section{Acknowledgements}

The authors thank the support to this investigation by the Brazilian agencies: CNPq, CAPES, FAPERJ

\section{REFERENCES}

1 CHAWLA, K.K. Composite Materials, New York: Springer-Verlag, (1993).

2 Monteiro, S.N., Lopes, F.P.D., Ferreira, A.S., Nascimento, D.C.O. Natural fiber polymer matrix composites: cheaper, tougher and environmentally friendly, JOM, 61 (2009) 1722.

3 WAMBUA, P.; IVENS, I.; VERPOEST, I. Natural fibers: can they replace glass and fiber reinforced plastics?" Comp. Sci. Technol. v. 63, p. 1259-1264, 2003. 
4 MOHANTY, A.K., MISRA M., HINRICHSEN, G. Biofibers, biodegradable polymers and biocomposites: an overview. Macromolecular Mat. and Engineering, 276/277, p. 1-24, 2000.

5 MONTEIRO, S.N., LOPES, F.P.D., FERREIRA A.S., NASCIMENTO, D.C.O. Natural fiber polymer matrix composites: cheaper, tougher and environmentally friendly. JOM, 61(1), pp. 17-22, 2009.

6 CROCKER, J., "Natural materials innovative natural composites". Materials Technology, 2-3 (2008) 174-178.

7 ANGELINI, L. G.; LAZZERI, A.; LEVITA, G.; FONTANELLI, D.; BOZZI, C. Ramie (Boehmeria nivea (L.) Gaud.) and Spanish Broom (Spartium junceum L.) fibers for composite materials: agronomical aspects, morphology and mechanical properties, Industrial Crops and Products, v.11(2-3), p.145-161, 2000

8 SHIHONG, L.; BENLIAN, Z.; QIYUN, Z.; XIANRONG, B., A new kind of super-hybrid composite material for civil use - ramie fibre/Al, Composites, v. 25(3), p. 225-228,1994

9 MONTEIRO, S. N., SATYANARAYANA, K. G., LOPES, F. P. D., High strength natural fibers for improved polymer matrix composites, Materials Science Forum, 638-642 (2010) 961-966.

10 MOHANTY, A.K., KHAN, M.A., HINRICHSEN, G. Influence of Chemical Surface Modification on the Properties of Biodegradable Jute Fabrics-Polyester Amide Composites. Composites: Part A, v. 31, p. 143-150, 2000.

11 LEI, W.; WEN-GUANG, L.; REN, C.; Effect of volume fraction of ramie cloth on physical and mechanical properties of ramie cloth/UP resin composite, Transactions of Nonferrous Metals Society of China, v. 16(2), p. 474-477, 2006. 